\title{
Histochemistry, content and chemical composition of essential oil in different organs of Alpinia zerumbet
}

\author{
Histoquímica, teor e composição química do óleo essencial nos diferentes órgãos de \\ Alpinia zerumbet
}

\author{
Caroline Nery Jezler ${ }^{\mathrm{I}}$ Ricardo Silva Batista ${ }^{\mathrm{I}}$ Péricles Barreto Alves ${ }^{\mathrm{II}}$ Delmira da Costa Silva ${ }^{\mathrm{I}}$ \\ Larissa Corrêa do Bomfim Costa $^{\mathrm{I}^{*}}$
}

\section{ABSTRACT}

Alpinia zerumbet is a medicinal plant from Asian origin used in folk medicine for the treatment of hypertension, which effect is attributed to terpinen-4-ol, the major component of the essential oil. The objective of this work was to identify the essential oil secretory structures in the leaf, flower, root and rhizome of this plant, and analyze the content and the chemical composition of the oil in the different organs of the plant. Sections were subjected to histochemical test with Nadi reagent for in situ localization of secretion. The essential oil extraction was performed by hydrodistillation in a Clevenger apparatus and the compounds were identified in CG-EM/FID. The histochemical test was positive for terpenoids, confirming the presence of essential oil stored in secretory structures named oils cells present in all analyzed organs. The higher essential oil content was found on the leaf $(0.30 \%)$, while the petal and the rhizome presented content of $0.10 \%$ and $0.06 \%$, respectively. It was not possible to determine essential oil content of the root due to the low amount of biomass produced. There were qualitative and quantitative differences in the chemical composition of the essential oil in the different plant organs, but the major constituent in all of them was the terpinen-4ol, followed by 1,8 cineol in the leaf and by the $\alpha$-terpineol in the flower and rhizome.

Key words: medicinal plant, terpinen-4-ol, secretory structure.

RESUMO

\footnotetext{
Alpinia zerumbet é uma planta medicinal de origem asiática, utilizada na medicina popular para o tratamento da hipertensão, cujo efeito é atribuído ao constituinte terpinen-4-ol, que está presente majoritariamente no óleo essencial. Objetivouse com este trabalho identificar as estruturas secretoras de óleo essencial na folha, flor, rizoma e raiz dessa planta e analisar o teor e a composição química do óleo nos diferentes órgãos do vegetal. Para localização in situ da secreção, cortes foram submetidos
}

ao teste histoquímico com reagente de Nadi. A extração do óleo essencial foi realizada por hidrodestilação em aparelho de Clevenger e a identificação dos compostos em CG-EM/FID. O teste histoquímico foi positivo, confirmando a presença de óleo essencial armazenado em estruturas secretoras do tipo células oleíferas em todos os órgãos analisados. O maior teor de óleo essencial foi verificado na folha ( $0,30 \%)$, enquanto a flor e o rizoma apresentaram teor de 0,10\% e 0,06\%, respectivamente, não sendo possível a determinação na raiz, devido à baixa quantidade de biomassa produzida. Houve diferenças qualitativas e quantitativas na composição química do óleo essencial nos diferentes órgãos da planta, mas o constituinte majoritário em todos eles foi o terpinen4-ol, acompanhado pelo 1,8 cineol na folha e pelo $\alpha$-terpineol na flor e rizoma.

Palavras-chave: planta medicinal, terpinen-4-ol, estrutura secretora.

\section{INTRODUCTION}

Alpinia zerumbet (Pers.) B.L. Burtt. \& R.M. Smith is an aromatic plant, herbaceous, with rhizomatous stem, long and sharpened leaves and semi-pendent inflorescences (LORENZI \& MATOS, 2008). This species has a wide distribution in Brazil and is widely used in folk medicine as a sedative and hypotensive, whose applications are justified by studies showing its antihypertensive effect by vasodilator action (BOTREL et al., 2009; FONSECA et al., 2002; LAHLOU et al., 2003; MOURA et al., 2005). Moreover, other studies have also found muscle relaxant and antispasmodic activities of the intestine (LAHLOU et al., 2003), hepatoprotective

\footnotetext{
'Departamento de Ciências Biológicas, Universidade Estadual de Santa Cruz (UESC), 45662-900, Ilhéus, BA, Brasil. E-mail: larissa@uesc.br. *Autor para correspondência.

"Departamento de Química, Universidade Federal de Sergipe (UFS), São Cristóvão, SE, Brasil. 
and antiarteriosclerosis activity of this plant (FONSECA et al., 2002; LI et al., 2008).

Among the different chemical components, the species has flavonoids, essential oils (MENDONÇA et al., 1991; ALBUQUERQUE \& NEVES, 2004), tannins, phenols and alkaloids (MENDONÇA et al., 1991) which are responsible for some of its therapeutic effects. The essential oil analysis from A. zerumbet leaves revealed the presence of 17 compounds, with p-cymene, 1,8-cineole, the $\gamma$-terpinene and terpinen-4-ol as the main constituents (MURAKAMI et al., 2009). Because of the importance of this medicinal species, many efforts have been devoted to the study of its chemical composition, but without the same interest in the knowledge of the location of these secondary compounds in different organs of the plant.

Depending on the taxonomic group under study, the essential oil can be found in various secretory structures such as glandular trichomes, cavities, ducts and oil cells. In addition, different species may accumulate active principles distributed throughout the plant or concentrated only in certain organs (SIMÕES \& SPITZER, 2000). Especially for Alpinia zerumbet, research has proven the existence of essential oil in the rhizomes (CHEN et al., 2008), leaves (LAHLOU et al., 2003; MOURA et al., 2005), flowers (ZOGHBI et al., 1999; ELZAAWELY et al., 2007) and seeds (LI et al., 2008), but in terms of anatomical structures was investigated only the leaf of the species (ALBUQUERQUE \& NEVES, 2004; VICTÓRIO et al., 2011).

Thus, this paper aims to provide information about the secretory structures and their contents located in the leaf, flower, root and rhizome of $\boldsymbol{A}$. zerumbet as well as the content and the chemical composition of secretions in these organs.

\section{MATERIAL AND METHODS}

Plants grown in the UESC Medicinal Plant Garden with about three years old were harvested at 8 am to perform the experiment. A herbarium voucher specimen was deposited at the HUESC herbarium under registration number 14088 and identified by Caroline Nery Jezler.

\section{Secretory structures identification}

For histochemical testing, four samples of fresh leaf, petal, root and rhizome were taken from two individuals and were freehand cross-sectioned and stained with Nadi reagent for detection of essential oil (DAVID \& CARDE, 1964). The results were recorded by digital camera attached to Olympus photomicroscope.

\section{Essential oil extraction}

The essential oil quantification of the different plant organs was performed by hydrodistillation in modified Clevenger apparatus with $100 \mathrm{~g}$ of fresh biomass and $1.5 \mathrm{~L}$ of distilled water in triplicate for 60 minutes. The hydrolate was subjected to liquid-liquid partition with triple washing of $10 \mathrm{~mL}$ dichloromethane. The organic fractions were subjected to drying with anhydrous sodium sulfate and after a few minutes resting, the solution was filtered and stored at room temperature in dark bottles partially covered in exhaustion chamber, until complete solvent evaporation. The masses of oils were determined to calculate the content $\left(\mathrm{g} 100 \mathrm{~g}^{-1}\right.$ dry biomass).

One-way analysis of variance and a Tukey test were used to determine the significance of essential oil content among plant organs $(\mathrm{P}<0.05)$.

\section{Essential oil chemical analyses}

Qualitative analysis of the essential oil was performed in the Laboratory of Chromatography, Department of Chemistry, Federal University of Sergipe, in the following conditions: a qualitative analysis was performed by gas chromatography coupled to mass spectrometry GC-MS (Shimadzu, modelQP5050A) equipped with autoinjetor AOC-20i (Shimadzu) and a capillary column of fused silica J \&W Scientific (5\%-phenyl-95\%dimethylpolysiloxane) $30 \mathrm{mx} 0.25 \mathrm{~mm} \mathrm{id,} 0.25 \mu \mathrm{m}$

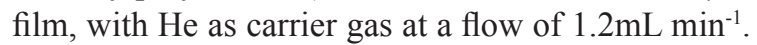
The temperature was programmed maintaining $50^{\circ} \mathrm{C}$ for $1.5 \mathrm{~min}$, followed by an increase of $4^{\circ} \mathrm{C} \mathrm{min}^{-1} \mathrm{up}$ to $200^{\circ} \mathrm{C}$, then at $10^{\circ} \mathrm{C}$ until reaching $280^{\circ} \mathrm{C}$ keeping this temperature constant for $5 \mathrm{~min}$; the injector temperature was $250^{\circ} \mathrm{C}$ and detector temperature (or interface) $280^{\circ} \mathrm{C} ; 0.5 \mu \mathrm{l}$ of ethyl acetate was injected with rate partition of $1: 8$ and pressure in column of $64.20 \mathrm{kPa}$. The MS was operating with ion capture detector for electron impact and impact energy of 70 $\mathrm{eV}$, scan speed 1,000; scan interval of 0.50 fragments $\mathrm{s}^{-1}$ and detection of fragments in range of 40-500Da.

Quantitative analysis of the constituents were performed on a gas chromatograph equipped with a flame ionization detector (FID) using a Shimadzu GC-17A, under the following operating conditions: fused silica capillary column ZB-5MS (5\% dimethylpolysiloxane) with $30 \mathrm{mx} 0.25 \mathrm{~mm}$ id 
$\mathrm{x} 0.25 \mu \mathrm{m}$ film, using the same conditions of GCMS. The quantification of the constituents was achieved by a reanormalization (\%). The compounds concentrations were calculated by the area and arranged in order of elution from the GC.

The oil components were identified by comparison of their mass spectra in the literature (ADAMS, 2004) with the database spectra (NIST21 and NIST107) equipment, and also by comparing retention indices with those of literature. The Kovats retention indices (KI) were determined using a homologous series of n-alkanes $\left(\mathrm{C}_{8}-\mathrm{C}_{18}\right)$ injected under the same chromatographic conditions of the samples, using the equation VAN DEN DOOL \& KRATZ (1963).

\section{RESULTS AND DISCUSSION}

The Nadi reaction resulted in an intense blue staining of the secretion contained in some cells in different regions of the analyzed organs, confirmed the presence of essential oils (Figure 1). In mesophyll were observed oil cells distributed in the palisade and spongy parenchyma (Figure 1A). In petal, the oil cells were found in the epidermis and in the parenchyma (Figure 1B). In the rhizome oil cells were identified in the cortical and medullar tissue (Figure 1C), while in the root the oil cells were located in the cortical region (Figure 1D).

The essential oils may be produced in many secretory structures comprising glandular trichomes, secretory cavities, ducts and oil cells which may vary with the botanical family (SIMÕES \& SPITZER, 2000). The identification of oil cells confirms previous studies restricted to the leaf of A. zerumbet (ALBUQUERQUE \& NEVES, 2004; VICTÓRIO et al., 2011) and expands knowledge recording the presence of these structures also in other organs of this species.

It was found variation on oil content according to the organ examined. Leaves showed significantly higher content $(0.30 \%)$ when compared with the content of flower $(0.10 \%)$ and rhizome $(0.06 \%)$, which did not differ statistically (Figure 2 ). Although oil cells were found in the roots of the plant, it was not possible to determine the content of essential oil due to the low amount of biomass obtained. The content of essential oil produced by the plant may seem low at first sight, but the plant is perennial and produces leaves the entire year ensured regular supply of raw material for commercial exploitation.

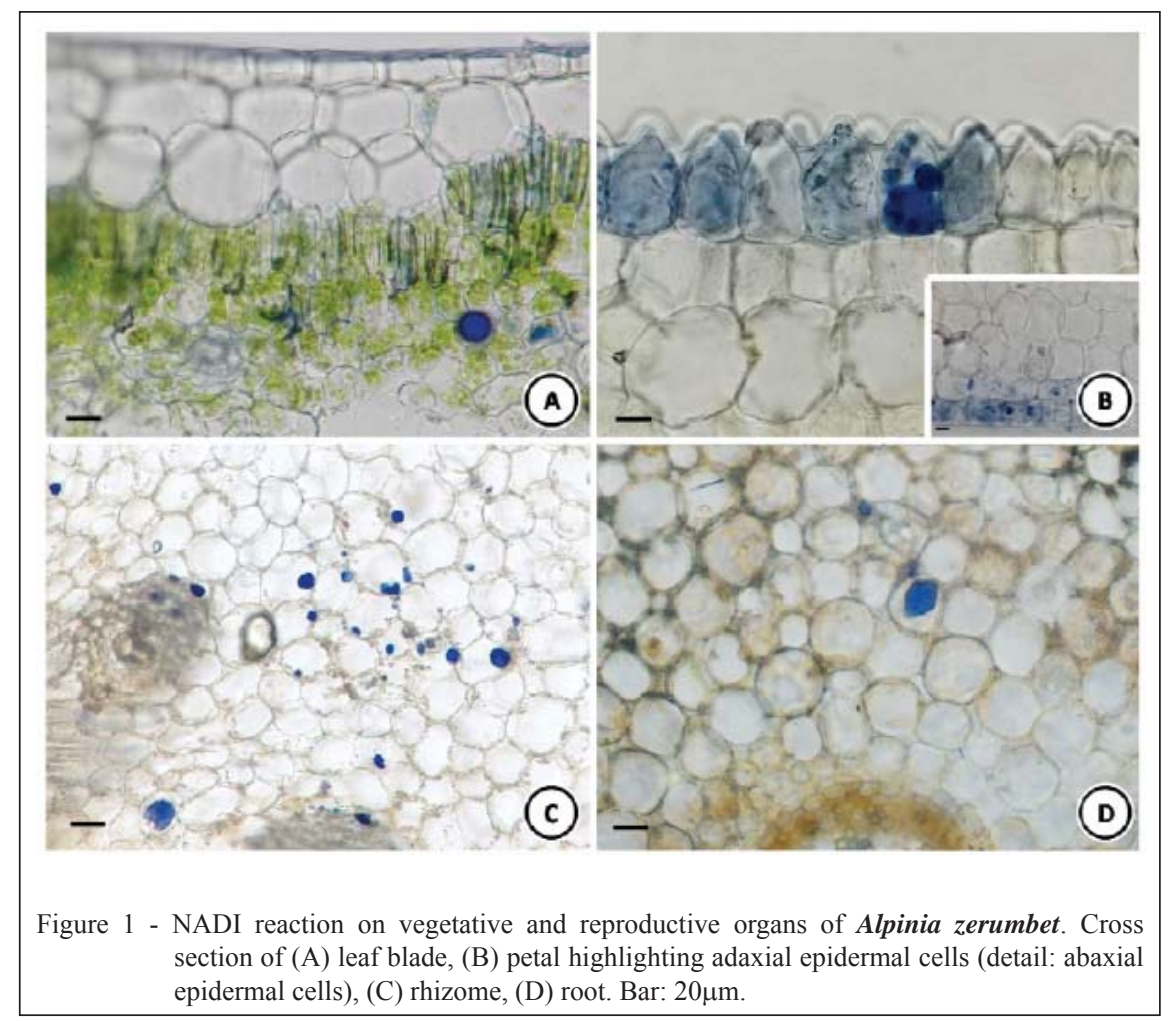

Ciência Rural, v.43, n.10, out, 2013. 


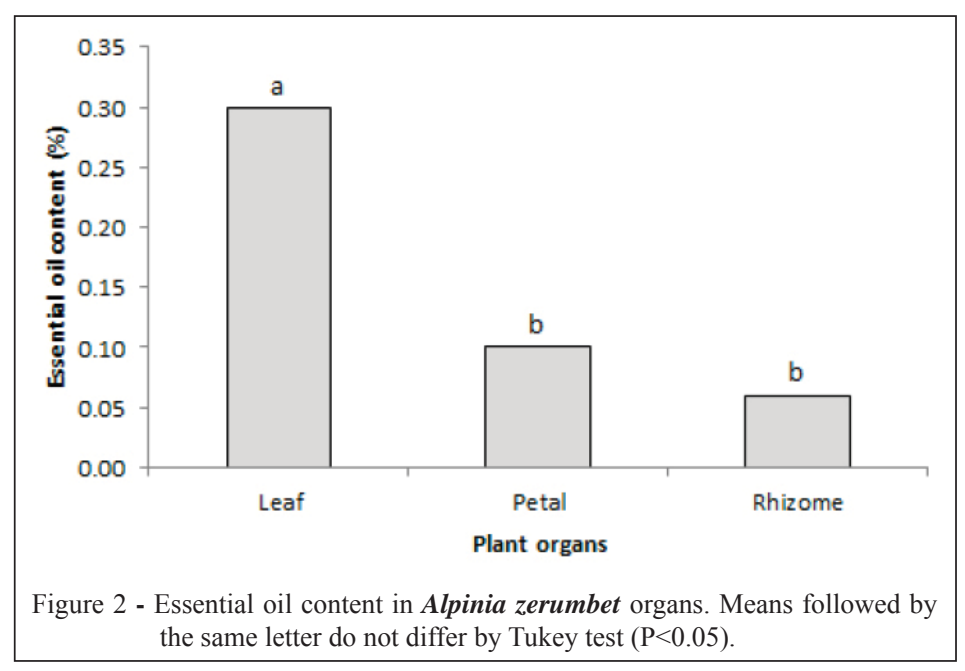

Differences in the distribution of the essential oil content in different organs of the plants seem to vary according to species as observed in other medicinal plants as Hyptis marrubioides (BOTREL et al., 2009) and Hyptis suaveolens (SILVA et al., 2003) which, unlike A. zerumbet, showed the highest essential oil content in inflorescences than in stems and leaves.

The analysis of the essential oil of $\boldsymbol{A}$. zerumbet revealed differences in their chemical composition in the different plant organs, such as the presence of 23 constituents in the flower, 20 in the leaf and 18 in the rhizome. The major constituent terpinen-4-ol was present in all plant organs in different quantities, followed by $\alpha$-terpineol in flower and rhizome and by 1,8 cineol in the leaf (Table 1).

Some constituents such as p-cymene, 1,8 cineol, $\gamma$-terpinene and linalool were found in the essential oil only of the flower and leaf, but absent in the rhizome. Quantitative differences were found in constituents of the three plant organs in cis-p-menth-2-en-1-ol, trans-p-menth-2-en-1-ol, terpinen-4-ol, $\alpha$-terpineol, piperitol trans-piperitol, ethyl isoborneol, $\alpha$-eudesmol, caryophyllene oxide. Also qualitative differences could be seen among the different organs such as the presence of unique chemical compounds in the flowerlike camphor, $\delta$-terpineol, dauceno, $\alpha$-humulene, $\gamma$-cadinene, elemoland (E) nerolidol, while other constituents as sabinene, $\beta$-pinene, $\alpha$-terpinene, limonene, cissabinene hydrate,terpinolene and trans-sabinene hydrate were present only in the leaf and endo-ethyl fenchilaand10-epi- $\gamma$-eudesmolonly in the rhizome.

Some of the essential oil constituents found in this study as p-cymene, $\gamma$-terpinene, 1,8 cineol and terpinen-4-ol (MURAKAMI et al., 2009), which assigned the hypotensive effect of the plant (BOTREL et al., 2009; FONSECA et al., 2002; LAHLOU et al., 2003; MOURA et al., 2005), confirms previous research with the same species. It is common to find variation in the chemical composition of the essential oil in different organs of a plant, as already seen in Ocimum basilicum (CHALCHAT \& OZCAN, 2008) and Eryngium amethystium (FLAMINI et al., 2008). The significant differences found in the components and relative contents of the essential oils of flowers, stem and leaves from $A$. zerumbet have a great range of potential utilities and a prospect of development. The presence of $10.84 \%$ of 1,8 cineol in leaves, for instance, would indicate a potentially antimicrobial and pesticide action not yet studied for this species, that which deserves to be verified in another study.

\section{CONCLUSION}

Secretory structures like oil cells were found in all organs of Alpinia zerumbet, however there was variation in the chemical composition and essential oil content. The major component, terpinen4-ol, was found throughout the plant, but the leaf was the organ with the highest essential oil content, therefore is more suitable for use in pharmaceutical or pharmacological preparations when seeking the hypotensive effect of the plant.

\section{ACKNOWLEDGMENT}

The authors thanks Conselho Nacional de Desenvolvimento Científico e Tecnológico (CNPq) for its financial support.

Ciência Rural, v.43, n.10, out, 2013. 
Table 1 - Percentage of chromatographic peak area corresponding to the identified compounds in the essential oil of flower, leaf and rhizome of Alpinia zerumbet.

\begin{tabular}{|c|c|c|c|c|}
\hline Compound & IK & Petal & Leaf & Rhizome \\
\hline sabinene & 975 & - & 1.42 & - \\
\hline$\beta$-pinene & 979 & - & 0.30 & - \\
\hline$\alpha$-terpinene & 1017 & - & 0.68 & - \\
\hline p-cymene & 1024 & 0.28 & 4.11 & - \\
\hline limonene & 1029 & - & 0.61 & - \\
\hline 1,8 cineol & 1031 & 3.37 & 10.84 & - \\
\hline$\gamma$-terpinene & 1059 & 0.94 & 5.71 & - \\
\hline cis-sabinene hydrate & 1070 & - & 0.63 & - \\
\hline terpinolene & 1088 & - & 1.24 & - \\
\hline linalool & 1096 & 5.11 & 1.76 & - \\
\hline trans- sabinene hydrate & 1098 & - & 0.91 & - \\
\hline cis-p-menth-2-en-1-ol & 1121 & 1.73 & 2.34 & 1.33 \\
\hline trans-p-menth-2-en-1-ol & 1140 & 1.52 & 1.74 & 2.33 \\
\hline camphor & 1146 & 0.60 & - & - \\
\hline$\delta$-terpineol & 1166 & 0.54 & - & - \\
\hline borneol & 1169 & 0.53 & - & 2.36 \\
\hline terpinen-4-ol & 1177 & 60.66 & 55.72 & 52.26 \\
\hline$\alpha$-terpineol & 1188 & 9.06 & 4.21 & 12.83 \\
\hline trans-piperitol & 1208 & 0.93 & 0.87 & 2.59 \\
\hline endo-ethyl fenchila & 1220 & - & - & 0.77 \\
\hline ethyl isoborneol & 1285 & 1.06 & 0.41 & 0.79 \\
\hline dauceno & 1381 & 0.56 & - & - \\
\hline$\beta$-cariofilene & 1419 & 2.49 & 1.12 & - \\
\hline$\alpha$-humulene & 1454 & 0.51 & - & - \\
\hline$\gamma$-cadinene & 1513 & 0.30 & - & - \\
\hline elemol & 1559 & 0.39 & - & - \\
\hline (E) nerolidol & 1563 & 1.12 & - & - \\
\hline caryophyllene oxide & 1583 & 1.63 & 3.83 & 5.04 \\
\hline carotol & 1594 & 0.89 & - & 2.24 \\
\hline 10-epi- $\gamma$-eudesmol & 1623 & - & - & 1.01 \\
\hline$\gamma$-eudesmol & 1632 & 2.33 & - & 1.63 \\
\hline$\alpha$-eudesmol & 1653 & 1.94 & 0.65 & 3.96 \\
\hline not identificated & - & - & - & 1.05 \\
\hline not identificated & - & - & - & 0.94 \\
\hline not identificated & - & - & - & 1.27 \\
\hline not identificated & - & - & - & 1.57 \\
\hline not identificated & - & - & - & 1.16 \\
\hline Total & & $98.49 \%$ & $99.10 \%$ & $95.13 \%$ \\
\hline
\end{tabular}

$\mathrm{KI}=$ Kovats Index.

\section{REFERENCES}

ADAMS, R.P. Identification of essential oil components by gas chromatography/quadrupopole mass spectroscopy. Illinois USA: Allured Publishing, 2004. 456p.

ALBUQUERQUE, E.S.B.; NEVES, L.J. Anatomia foliar de Alpinia zerumbet (Pers.) Burtt \& Smith (Zingiberaceae). Acta
Botânica Brasílica, v.18, n.1, p.109-121, 2004. Available from: $<$ http://www.scielo.br/scielo.php?script=sci_arttext\&pid=S010233062004000100010\&lng=en\&nrm=iso>. Accessed: fev 01, 2013. doi: 10.1590/S0102-33062004000100010.

BOTREL, P.P. et al. Teor e composição química do óleo essencial de Hyptis marrubioides Epling (Lamiaceae) em diferentes genótipos. Revista Brasileira de Plantas Medicinais, v.11, n.2, 
p.164-169, 2009. Available from: <http://www.scielo.br/scielo. php?script $=$ sci_arttext\&pid $=$ S 1516-05722009000200009\&lng $=$ en $\& n r m=$ iso $>$. Accessed: fev 01, 2013. doi: 10.1590/S151605722009000200009 .

CHALCHAT, J.-C.; OZCAN, M.M. Comparative essential oil composition of flowers, leaves and stems of basil (Ocimum basilicum L.) used as herb. Food Chemistry, v.110, n.2, p.501503, 2008.

CHEN I.-N. et al. Antioxidant and antimicrobial plants in Taiwan. Plant Foods for Human Nutrition, v.63, n. 1, p.15-20, 2008.

DAVID, R.; CARDE, J.P. Coloration différentielle des inclusions lipidiques et terpéniques des pseudophylles du Pin maritime au moyen du réactif Nadi. Comptes Rendus Hebdomadaires des Séances de l'Académie des Sciences, v. 258, p.1338-1340, 1964.

ELZAAWELY, A.A. et al. Antioxidant activity and contents of essential oil and phenolic compounds in flowers and seeds of Alpinia zerumbet (Pers.) B.L. Burtt. \& R. M. Sm. Food Chemistry, v.104, n.4, p.1648-1653, 2007.

FLAMINI, G. et al. Composition of the essential oils from leafy parts of the shoots, flowers and fruits of Eryngium amethystinum from Amiata Mount (Tuscany, Italy). Food Chemistry, v.107, n.2, p.671-674, 2008. Available from: $<$ http://www.sciencedirect.com/ science/article/pii/S0308814607008722>. Accessed: fev 01, 2013. doi: 10.1016/j.foodchem.2007.08.064.

FONSECA, F.A.H. et al. Hipertensão e dislipidemias. Revista Brasileira Hipertensão, v.9, p.268-272, 2002.

LAHLOU, S. et al. Antihypertensive effects of the essential oil of Alpinia zerumbet and its main constituent, terpinen-4-ol, in DOCA-salt hypertensive conscious rats. Fundamental \& Clinical Pharmacology, v.17, n.3, p.323-30, 2003. Available from: <http:// onlinelibrary.wiley.com/doi/10.1046/j.1472-8206.2003.00150.x/ full>. Accessed: fev 01, 2013. doi: 10.1046/j.14728206.2003.00150.x
LI, L.Y. et al. Alpinia zerumbet potentially elevates high-density lipoprotein cholesterol level in hamsters. Journal of Agricultural and Food Chemistry, v.56, n.12, p.4435-4443, 2008. Available from: <http://pubs.acs.org/doi/abs/10.1021/jf800195d >. Accessed: fev 01, 2013. doi: 10.1021/jf800195d.

LORENZI, H.; MATOS, F.J.A. Plantas medicinais no Brasil: nativas e exóticas. São Paulo: Instituto Plantarum, 2008. 544p.

MENDONÇA, V.L.M. et al. Pharmacological and toxicological evaluation of Alpinia speciosa. Memórias do Instituto Oswaldo Cruz, v.86, p.93-97, 1991.

MOURA, R.S. et al. Endothelium-Dependent vasodilator effects of Alpinia zerumbet, a medicinal plant. Journal of Cardiovascular Pharmacology, v.46, n.3, p.288-294, 2005.

MURAKAMI, S. et al. Composition and seasonal variation of essential oil in Alpinia zerumbet from Okinawa Island. Journal of Natural Medicines, v.63, n.2, p.204-208, 2009.

SILVA, A.F. et al. Composição química do óleo essencial de Hyptis suaveolens (L.) Poit. (Lamiaceae). Revista Brasileira de Plantas Medicinais, v.6, n.1, p.1-7, 2003.

SIMÕES, C.M.O.; SPITZER, V. Óleos voláteis. In: SIMÕES, C.M.O. et al. Farmacognosia: da planta ao medicamento. Porto Alegre: UFRGS, 2000. p.387-416.

VICTÓRIO, C.P. et al. Leaf volatiles and secretory cells of Alpinia zerumbet (Pers.) Burtt et Smith (Zingiberacea). Natural Product Research, v.25, n.10, p.939-948, 2011.

VAN DEN DOOL, H.; KRATZ, P.D.J. A generalization of the retention index system including linear temperature programmed gasliquid partition chromatography. Journal of Chromatography, v.11, p.463-471, 1963.

ZOGHBI, M.G.B. et al. Volatile constituents from leaves and flowers of Alpinia speciosa K. Schum. and A. purpurata (Viell.) Schum. Flavour and Fragrance Journal, v.14, p.411-414, 1999. 